\title{
軟岩におけるバケット系掘削機の刃先作用力に 関する実験的研究
}

\author{
室 達朗* ・深川良一 ${ }^{* *} \cdot$ 渡辺裕明***
}

\begin{abstract}
本研究の目的は, 軟岩に対するバケット系掘削機の刃先に作用する非定常掘削抵抗之 刃先の軌跡, 及び掘削土量について実験的考察を行うことである. 刃先に作用する掘削 抵抗は掘削距離, 鉛直貫入力, 軟岩のせん断強度及び刃先のすくい角の関数として表さ れ, そして, 刃先の貫入抵抗係数は軟岩のせん断強度の増加と共に大きくなるが, すく い角約 $10^{\circ}$ のとき最小値となることを明らかにした。 また, 種々の実験・解析結果に基 づき, 刃先の軌跡を算出し, さらにその軌跡から掘削土量を導き出し, 諸因子による影 響を明らかにした。
\end{abstract}

Keywords : soft rock, unsteady excavation, locus, cutting edge, volume

\section{1. まえがき}

実際のバケット系掘削機械は, 掘削深さの変化する非 定常掘削機構を有しているものが多いにもかかわらず, 未だにその詳細な掘削の機構は解明されていない. そこ で本研究は, 軟岩を対象とした非定常掘削に関する基礎 的な解析之考察を行ったものである. 種々の実験結果を 基礎として, 主に刃先作用力と掘削土量について解析を 展開した。最終的には実機へ適用し, 実験・解析の妥当 性を確かめた。ここで用いたパラメー夕は，すくい角， 掘削距離, 鉛直貫入力, 軟岩のせん断強度であるが, こ の内軟岩のせん断強度以外は, 掘削機械の諸元で定まる ものである. よって, 軟岩の力学特性が得られれば, 直 ちに刃先作用力および掘削土量が算出できる実験式とプ ログラムを確立すること，同時に，それらが実機に対し て有益な設計指針を与えるものであるか否かを確認する ことを, 本研究の目的としている.

\section{2. 軟岩供試体}

本研究は軟岩を対象としたものであるが, 軟岩と呼ば れている岩石に対する定義に確かなものはない. ISRM の manual index test ${ }^{1}$ によれば，一軸圧縮強度が約 245 $\sim 4900 \mathrm{kPa}$ の岩石を極度に弱い岩石としている. 本研 究では, 海底の軟弱な岩盤となりうるこの程度の強度を 持つ岩石を軟岩之定義し, 実験・解析を進めた. 実験で 用いる軟岩は, 本来なら天然のものを現場から採取して くるのが最良であるが, それは極めて困難である.また， 自然状態のままの軟岩は様々な風化作用を受け，層理・ 亀裂等の存在が基礎的な掘削実験には好ましくない。そ

\footnotetext{
* 正会員 工博 愛媛大学教授 工学部 土木海洋工学科 ( ₹790 松山市文京町 3)

**正会員 工博 愛媛大学助教授 工学部 土木海洋工学科 *** 学生会員 工修 愛媛大学大学院生
}

Table 1 Combination ratios and mechanical properties of soft rock model

\begin{tabular}{|r|c|c|c|}
\hline $\begin{array}{r}\text { cement water ratio } \\
\mathrm{C} / \mathrm{W}(\%)\end{array}$ & 4.9 & 13.8 & 38.5 \\
\hline soil S (N) & 284.2 & 269.5 & 225.4 \\
\hline cement $\mathrm{C} \mathrm{(N)}$ & 8.53 & 24.30 & 67.62 \\
\hline water W (N) & 175.4 & 176.2 & 175.8 \\
\hline $\begin{array}{l}\text { unconfined compressive } \\
\text { strength } \quad S_{c}(\mathrm{kPa})\end{array}$ & $173 \pm 72$ & $1023 \pm 433$ & $2636 \pm 597$ \\
\hline $\begin{array}{l}\text { radial compressive } \\
\text { strength } S_{t}(\mathrm{kPa})\end{array}$ & $20.6 \pm 9.8$ & $104.9 \pm 44.1$ & $303.8 \pm 67.6$ \\
\hline $\begin{array}{r}\text { shear strength } \\
S_{S}(\mathrm{kPa})\end{array}$ & $37.2 \pm 16.7$ & $198.0 \pm 82.3$ & $553.7 \pm 121.5$ \\
\hline
\end{tabular}

こでここでは，亀裂および層理等のない軟岩供試体を 設計・製作し，実験に供した。供試体は，乾燥シルト質 ロームと普通ポルトランドセメントと水を混合擋汼して 製作した. Table 1 に， 3 種類の供試体の配合比を示し ている. 混合擋汼した試料を, 平面丕条件のもとで 150 $\mathrm{cm} \times 30 \mathrm{~cm} \times 5.4 \mathrm{~cm}$ の鋼製容器に打設し, 室内で 7 日 間湿潤養生させた後, 掘削実験に用いた。同時に, 直径 $5 \mathrm{~cm}$, 長さ $10 \mathrm{~cm}$ の円柱供試体を作成し, 一軸圧縮試験, 圧裂引張試験に供した. 配合の異なる 3 種類の供試体の それぞれの一軸圧縮強度 $S_{c}(\mathrm{kPa})$, 圧裂引張強度 $S_{t}$ $(\mathrm{kPa})$ およびせん断強度 $S_{s}(\mathrm{kPa})$ の平均値を同表に 示した.ここで, せん断強度 $S_{s}$ (は次式 $\left.{ }^{2}\right)$ より算出した。

$$
S_{s}=\frac{S_{c} \cdot S_{t}}{2 \sqrt{S_{t}\left(S_{c}-3 \cdot S_{t}\right)}} \quad(\mathrm{kPa})
$$

なお，掘削深さを一定とした定常掘削試験 ${ }^{3)}$ では，軟岩 の破壊形式は掘削刃のすくい角 $60^{\circ}$ まではせん断破壊す ることが判明しており, 以後軟岩の物性值はせん断強度 


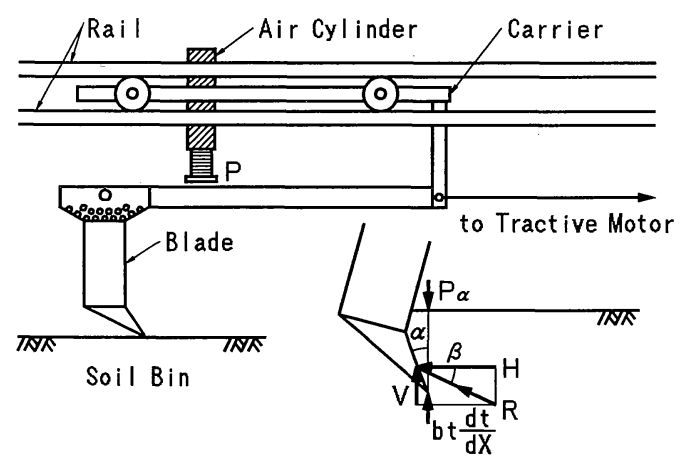

Fig.1 Excavation test apparatus of rock mass

で代表させることとした.

\section{3. 非定常掘削実験}

実験装置はFig.1 に示すように，エアシリンダー，台 車，掘削刃，土槽よりなる．また，図には描かれていな いが，牽引装置として $0.4 \mathrm{~kW}$ のモー夕も備えている。 掘削刃は根元の取り付ける位置を変えることにより，す くい角を一 $20^{\circ} \sim 60^{\circ}$ まで $10^{\circ}$ 間隔で変えることができ る. $P(\mathrm{~N})$ はエアシリンダーによる鉛直荷重, $P_{\alpha}(\mathrm{N} / \mathrm{cm})$ は，エアシリンダーによって刃先に与えられる鉛直貫入 力である. $H(\mathrm{~N} / \mathrm{cm})$ は水平掘削抵抗, $V(\mathrm{~N} / \mathrm{cm})$ は 鉛直掘削抵抗, $R(\mathrm{~N} / \mathrm{cm})$ は $H$ と $V$ の合力である合掘 削抵抗を表す.また, $b t \cdot d t / d X$ はくい込み抵抗を表し， $b(\mathrm{kPa})$ は貫入抵抗係数, $t(\mathrm{~cm})$ は掘削深さ, $X(\mathrm{~cm})$ は掘削距離である， $\beta(\mathrm{deg})$ は， $R$ が作用する方向の 水平面からの角度， $\alpha(\mathrm{deg})$ はすくい角を表す。すく い角とは, 地盤の垂線と掘削刃面之の間の角度のことで ある. 力の方向は，それぞれ同図に示す矢印の方向を正 として解析した.

非定常掘削実験では，掘削刃取付部に作用している軸 カおよび曲げモーメントを掘削刃に貼付した歪ゲージに より測定した後, 刃先部に作用する $H, V+b t \cdot d t / d X$ に換算した．同時に，超音波変位計により $t$ を測定し， 刃先の通った軌跡を求めた。実験は， $\alpha$ を $-20^{\circ}$ から $10^{\circ}$ 間隔で $60^{\circ}$ までの 9 種類とし， $P_{\alpha}$ は，30.87 432.0 $\mathrm{N} / \mathrm{cm}$ の間でセメント水比 $C / W$ が $4.9 \%$ については 4 種類， $13.8 \% ， 38.5 \%$ については 5 種類ずつ変えて行っ た. よって一つのすくい角について 14 種類, 合計 126 種類の実験を行い, 解析・考察した。 刃幅は $5 \mathrm{~cm}$, 刃 先角は $30^{\circ}$ ，率引速度は $7.3 \mathrm{~cm} / \mathrm{min}$ で一定とした。

\section{4. 掘削抵抗}

Fig.2 は，実験結果の一例として $\alpha=10^{\circ}, C / W=$ $13.8 \%, P_{10}=183.8 \mathrm{~N} / \mathrm{cm}$ (添字はすくい角を表す) の 場合の $X$ と $H, V$ の関係を示したものである. 図より, $H$ は小さな上下動を繰り返しながら掘削が進むに従い

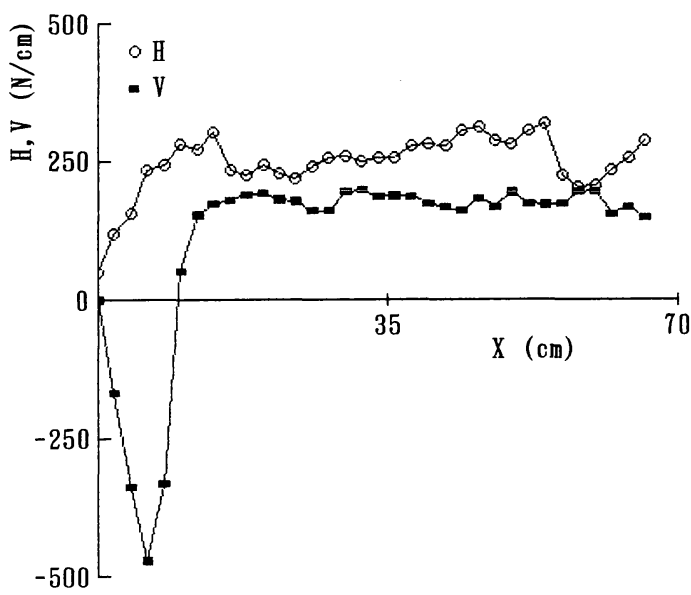

Fig.2 Relations between horizontal and vertical excavation force $H, V$ and excavation length $\left(\alpha=10^{\circ} \mathrm{C} / W=13.8 \%\right.$ $\left.P_{10}=183.8 \mathrm{~N} / \mathrm{cm}\right)$

Table $2 H_{\alpha}$ Constants in Eq. (2) after regression analysis

\begin{tabular}{|l|c|c|c|c|c|}
\hline & $\mathrm{H} 1$ & $\mathrm{H} 2$ & $\mathrm{H} 3$ & $\mathrm{H} 4$ & $\mathrm{Rc}$ \\
\hline $\mathrm{H}_{-20}$ & 0.457 & 0.122 & 1.04 & $4.48 \times 10^{-3}$ & 0.917 \\
\hline $\mathrm{H}_{-10}$ & 1.05 & $7.19 \times 10^{-2}$ & 0.973 & $-1.82 \times 10^{-3}$ & 0.948 \\
\hline $\mathrm{H}_{0}$ & 1.39 & 0.123 & 0.723 & 0.163 & 0.848 \\
\hline $\mathrm{H}_{10}$ & 1.04 & 0.154 & 0.852 & $8.99 \times 10^{-2}$ & 0.926 \\
\hline $\mathrm{H}_{20}$ & 0.974 & 0.218 & 0.756 & 0.172 & 0.934 \\
\hline $\mathrm{H}_{30}$ & 1.96 & 0.190 & 0.801 & $3.79 \times 10^{-2}$ & 0.802 \\
\hline $\mathrm{H}_{40}$ & 2.20 & 0.192 & 0.490 & 0.218 & 0.841 \\
\hline $\mathrm{H}_{50}$ & 1.31 & 0.217 & 0.582 & 0.156 & 0.798 \\
\hline $\mathrm{H}_{60}$ & 2.45 & $2.67 \times 10^{-2}$ & 0.707 & $5.21 \times 10^{-2}$ & 0.704 \\
\hline
\end{tabular}

わずかずつではあるが増加し，Vは掘削開始後一度負值 で極小値をとった後，これも小さな上下動はあるが，一 定値に落ち着く傾向がある. そして, その一定值は $P_{10}$ とほぼ等しくなっている. 一方, くい込み抵抗 $b t$. $d t / d X$ は，後述する式 (12) に示すように, $P_{10}$ と $V_{10}$ の差で与えられるので, 図より明らかに, $V$ の極小值を 与える $X$ において, 刃先のにげ面に作用するくい込み 抵抗が最大值に達し，さらに $X$ が増加するとすくい面 に作用する鉛直掘削抵抗が大きくなり，次第にくい込み 抵抗は減少するのである.小さな上下動の原因としては, 掘削刃の刃先前方の土は対数ら線状のすべり線が入って 破壊するので，すべり線が入った直後は抵抗は小さくな り, 掘削が進んで破壞されていない部分の土に刃先が達 すると，抵抗が大きくなるためであると考えられる．上 記の $H, V$ の挙動より，Rの作用角 $\beta$ は初期において 負之なり, その後, 正へと移行している. つまり， $R$ は掘削開始後時計回りに回転していることが分かる.

こうした実験結果より, 各 $\alpha$ に対する $H_{\alpha}, R_{\alpha}$ を従 
Table $3 R_{\alpha}$ Constants in Eq. (3) after regression analysis

\begin{tabular}{|l|c|c|c|c|c|}
\hline & $\mathrm{R} 1$ & $\mathrm{R} \mathrm{2}$ & $\mathrm{R} \mathrm{3}$ & $\mathrm{R} \mathrm{4}$ & $\mathrm{Rc}$ \\
\hline $\mathrm{R}_{-20}$ & 0.971 & 0.175 & 0.927 & $2.07 \times 10^{-2}$ & 0.894 \\
\hline $\mathrm{R}_{-10}$ & 1.07 & $9.61 \times 10^{-2}$ & 0.900 & $8.86 \times 10^{-2}$ & 0.941 \\
\hline $\mathrm{R}_{0}$ & 2.68 & 0.155 & 0.704 & $6.98 \times 10^{-2}$ & 0.846 \\
\hline $\mathrm{R}_{10}$ & 1.13 & 0.168 & 0.816 & 0.149 & 0.915 \\
\hline $\mathrm{R}_{20}$ & 1.18 & 0.216 & 0.731 & 0.223 & 0.863 \\
\hline $\mathrm{R}_{30}$ & 1.77 & 0.191 & 1.01 & $-5.92 \times 10^{-2}$ & 0.730 \\
\hline $\mathrm{R}_{40}$ & 0.933 & 0.393 & 0.470 & 0.609 & 0.866 \\
\hline $\mathrm{R}_{50}$ & 0.117 & 0.435 & 1.15 & 0.303 & 0.854 \\
\hline $\mathrm{R}_{60}$ & 1.07 & 0.230 & 0.780 & 0.298 & 0.788 \\
\hline
\end{tabular}

Table $4 V_{\alpha}$ Constants in Eq. (5) and Eq. (6) after regression analysis

\begin{tabular}{|l|c|c|c|c|c|c|c|}
\hline & $\mathrm{V} 1$ & $\mathrm{~V} 2$ & $\mathrm{~V} 3$ & $\mathrm{~V} 4$ & $\mathrm{~V} 5$ & $\mathrm{~V} 6$ & $\mathrm{Rc}$ \\
\hline $\mathrm{V}_{-20}$ & -0.268 & -0.881 & 1.87 & $\begin{array}{c}6.27 \\
\times 10^{-2}\end{array}$ & 0.448 & $\begin{array}{c}4.05 \\
\times 10^{2}\end{array}$ & 0.746 \\
\hline $\mathrm{V}_{-10}$ & $\begin{array}{c}-4.45 \\
\times 10^{-3}\end{array}$ & 0.326 & 1.37 & 3.03 & -0.294 & $\begin{array}{c}3.40 \\
\times 10^{-2}\end{array}$ & 0.764 \\
\hline $\mathrm{V}_{0}$ & -0.127 & 0.507 & 0.715 & $\begin{array}{c}5.61 \\
\times 10^{-2}\end{array}$ & 0.761 & $\begin{array}{c}-4.85 \\
\times 10^{-2}\end{array}$ & 0.766 \\
\hline $\mathrm{V}_{10}$ & $\begin{array}{c}-2.19 \\
\times 10^{-2}\end{array}$ & 1.04 & 0.661 & 0.270 & 0.841 & -0.341 & 0.802 \\
\hline $\mathrm{V}_{\mathbf{2 0}}$ & -2.46 & 0.240 & 0.697 & 4.88 & 0.750 & -0.641 & 0.789 \\
\hline $\mathrm{V}_{30}$ & -2.82 & 0.340 & 0.670 & 25.5 & 0.760 & -0.948 & - \\
\hline $\mathrm{V}_{40}$ & -5.39 & 0.210 & 0.660 & $\begin{array}{c}1.37 \\
\times 10^{2}\end{array}$ & 0.750 & -1.25 & - \\
\hline $\mathrm{V}_{\mathbf{5 0}}$ & -9.54 & $\begin{array}{c}8.00 \\
\times 10^{-2}\end{array}$ & 0.650 & $\begin{array}{c}6.87 \\
\times 10^{2}\end{array}$ & 0.740 & -1.55 & - \\
\hline $\mathrm{V}_{60}$ & -16.2 & $\begin{array}{c}-5.00 \\
\times 10^{-2}\end{array}$ & 0.640 & $\begin{array}{c}3.32 \\
\times 10^{2}\end{array}$ & 0.730 & -1.85 & - \\
\hline
\end{tabular}

属変数とし, $X, P_{\alpha}, S_{s}$ を独立変数として, 一般式を

$$
\begin{aligned}
& H_{\alpha}=H 1 \cdot X^{H_{2}} \cdot P_{\alpha}{ }^{H_{3}} \cdot S_{s}{ }^{H_{4}} \\
& R_{\alpha}=R 1 \cdot X^{R_{2}} \cdot P_{\alpha}{ }^{R_{3}} \cdot S_{s}{ }^{R_{4}}
\end{aligned}
$$

亡おいて重回帰分析を行った。Table 2 に $H_{\alpha}$ の回帰分 析結果を, Table 3 に $R_{\alpha}$ の回帰分析結果を示している. 表中の $R_{c}$ は相関係数を表す.

また， $V_{\alpha}$ は前述のように $X=X_{p}$ において一度極小值 $V_{p}$ をとった後, 一定値 $P_{\alpha}$ に落ち着くという挙動である ので，笈田の式 ${ }^{4)}$ 次のように変形して回帰した. $V_{\alpha}=$

$$
\begin{aligned}
& P_{\alpha}\left[1-\frac{\sqrt{1-\frac{P_{\alpha}}{V_{p}}} \exp \left(\frac{X}{X_{p}} \ln \left\{1+\frac{V_{p}}{P_{\alpha}}\left(\sqrt{1-\frac{P_{\alpha}}{V_{p}}}-1\right)\right\}\right)}{\sqrt{1-\frac{P_{\alpha}}{V_{p}}}\left(1-2 \frac{V_{p}}{P_{\alpha}}\right)+2 \frac{V_{p}}{P_{\alpha}}-2}\right] \\
& \times\left[1-\exp \left(\frac{X}{X_{p}} \ln \left\{1+\frac{V_{p}}{P_{\alpha}}\left(\sqrt{1-\frac{P_{\alpha}}{V_{p}}}-1\right)\right\}\right)\right] \cdots(4)
\end{aligned}
$$

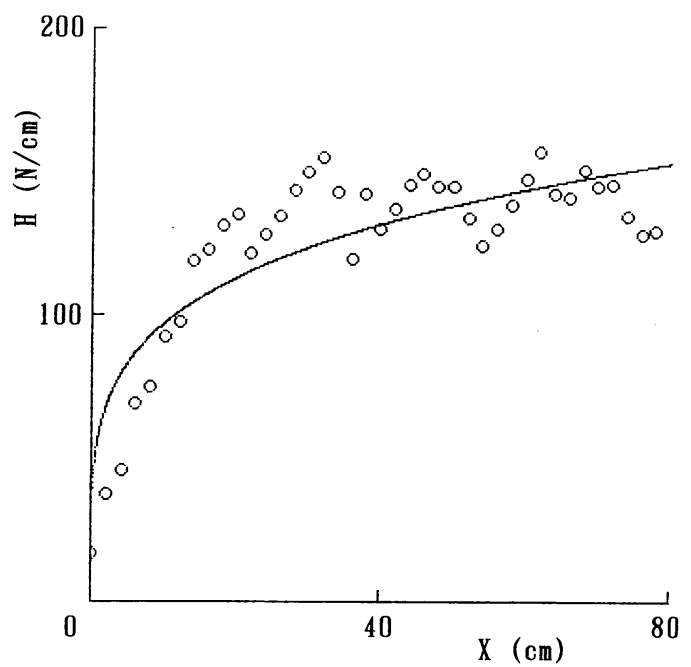

Fig.3 Relation between horizontal excavation force $H$ and excavation length $X\left(\alpha=20^{\circ} \quad C / W=4.9 \% \quad P_{20}=82.42\right.$ $\mathrm{N} / \mathrm{cm}$ )

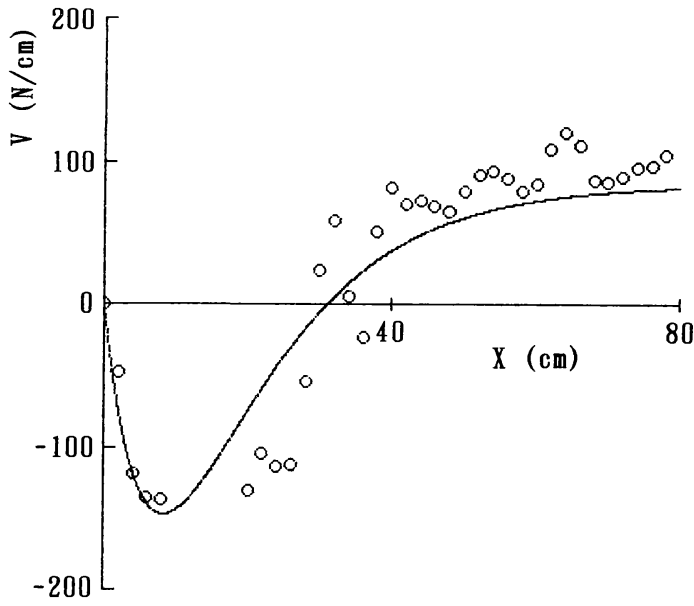

Fig.4 Relation between vertical excavation force $V$ and excavation length $X\left(\alpha=20^{\circ} \quad C / W=4.9 \% \quad P_{20}=82.42\right.$ $\mathrm{N} / \mathrm{cm}$ )

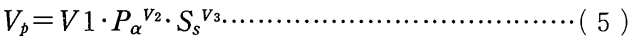

$$
\begin{aligned}
& X_{p}=V 4 \cdot P_{\alpha}^{V_{5}} \cdot S_{s}{ }^{V_{6}}
\end{aligned}
$$

その回帰分析結果をTable 4 に示す， $\alpha \geqq 30^{\circ}$ になると, 極小值 $V_{p}$ を示す $X_{p}$ がかなり増大し，実験の掘削距離 である $X \leqq 80 \mathrm{~cm}$ の範囲では， $V_{\alpha}$ には一定値に落ち着 く挙動が見られなかったので， $\alpha=0^{\circ} \sim 20^{\circ}$ の $V 1 \sim V 6$ を 用いてそれぞれについて単回帰分析を行い， $\alpha \geqq 30^{\circ}$ の $V 1$ V6 を推測した.

Fig.3，Fig.4は，上記のような回帰分析結果と実験 結果を比較したものである. Fig.3 は $X$ と $H$ の関係を, Fig.4 は $X$ と $V$ 関係を示したものであり, 条件は両 図とも $\alpha=20^{\circ}, C / W=4.9 \%, P_{20}=82.42 \mathrm{~N} / \mathrm{cm}$ である. 


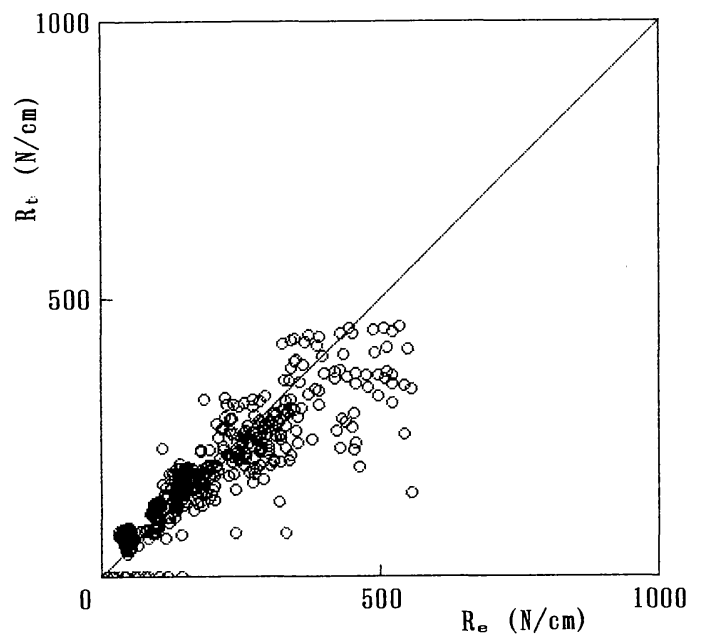

Fig.5 Relation between calculated value $R_{t}$ and measured one $R_{e}$ of resultant excavation force $R\left(\alpha=-10^{\circ}\right)$

図中のデータは実測値であり, 曲線は $\alpha=20^{\circ}$ の回帰曲 線を表す。 $H, V$ 共に, 実測値と回帰曲線は良く一致し ている.

さらに，すくい角が $\alpha^{\circ}$ のときの $H_{\alpha}, V_{\alpha}, R_{\alpha}$ とすく 认角が $0^{\circ}$ のときの $H_{0}, V_{0}, R_{0}$ との関係を，それぞれ $\alpha$ の関数によって表すことができれば， $H_{\alpha}, V_{\alpha}, R_{\alpha}$ は, $X, P_{\alpha}, S_{s}$ および $\alpha$ の関数で表すことができる. 香 ${ }^{5}$ に よれば, 粘性土および砂質土において, 次式の関係が得 られている.

$$
\frac{H_{\alpha}}{H_{0}}=10^{-m \alpha} \quad(m: \text { 定数 })
$$

ここに, 定数 $m$ は砂質土に対して 0.45 , 粘性土に対し て 0.22 である. 本研究においても, 前述の $H_{0}$ の回帰 式により算出した値で, $H_{\alpha}$ の回帰式により算出した值 を除した值の常用対数を従属変数とし， $\alpha$ を独立変数と して単回帰分析を行った. $\alpha=0^{\circ}$ を境にして,$\alpha<0^{\circ}$ と $\alpha \geqq 0^{\circ}$ では傾向が異なっていたので，二つを別々に回帰 した. $R_{\alpha}$ についても同様の分析を行い, その結果次式 を得た。

$$
\begin{aligned}
& \alpha<0^{\circ} \\
& \log \left(H_{\alpha} / H_{0}\right)=8.64 \times 10^{-3} \alpha \cdots \\
& \log \left(R_{\alpha} / R_{0}\right)=2.16 \times 10^{-3} \alpha \cdots \cdots \\
& \alpha \geqq 0^{\circ} \\
& \log \left(H_{\alpha} / H_{0}\right)=-2.02 \times 10^{-3} \alpha \cdots \\
& \log \left(R_{\alpha} / R_{0}\right)=1.17 \times 10^{-2} \alpha \cdots \cdots
\end{aligned}
$$

Fig.5は， $\alpha=-10^{\circ}$ において， $R$ の実測值 $R_{e}$ と式（9） の回帰式による算定値 $R_{t}$ を比較したものである. 図中 の直線は傾きが $45^{\circ}$ の直線であり, $R_{e}=500$ 付近を除い て $R_{e}$ と $R_{t}$ の両者は良く一致している. なお，軟岩の $S_{s}$ が増加すると $R_{e}$ が増大するが, 岩石の破壊様式は連

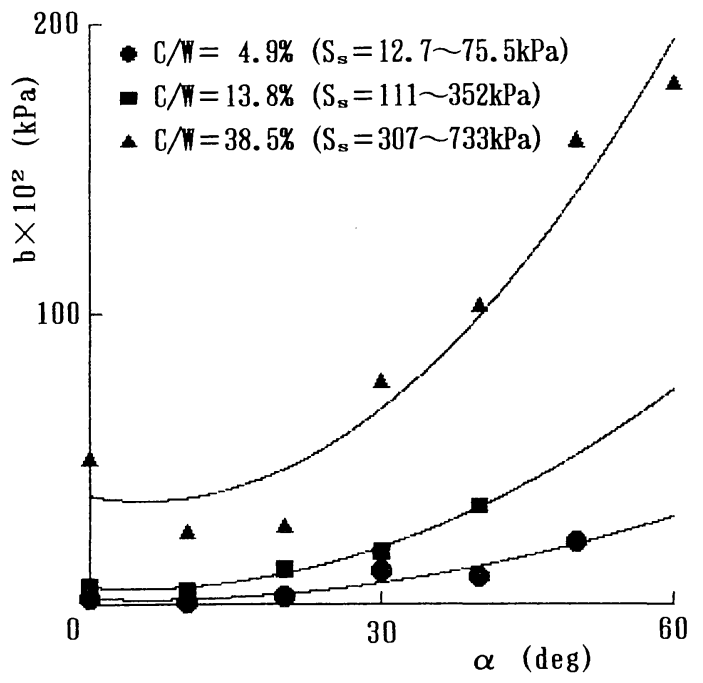

Fig.6 Relation between coefficient of penetration resistance $b$ and rake angle $\alpha\left(P_{\alpha}=31.75 \sim 432.0 \mathrm{~N} / \mathrm{cm}\right)$

続的な弾塑性破壊から断続的な剛塑性破壞へ移行し実測 值のばらつきが大きくなるため, $R_{e}$ と $R_{t}$ の相関性は低 下している.

\section{5. 貫入抵抗係数}

貫入抵抗係数 $\mathrm{b}(\mathrm{kPa})$ とは, 定常掘削には現れず非定 常掘削にのみ存在するくい込み抵抗を決定する上で重要 な係数であり，掘削刃のくい込みやすさの程度を表す指 標である. $b$ の值は畠による次式 ${ }^{6}$ により算出した。

$$
P_{\alpha}-V_{\alpha}=b t \frac{d t}{d X}
$$

右辺の $b t \cdot d t / d X$ がくい込み抵抗を表す. くい込み抵 抗が小さいほど掘削刃は良く貫入するので, $b$ の値が小 さいほ上゙掘削刃はくい込みやすいことになる。各 $C / W$ において実験デー夕を用いて式（12）により得られた $b$ を， $\alpha\left(\geqq 0^{\circ}\right)$ の 2 次関数として表し回帰分析を行った 結果, 以下の式が成立した.

$$
\begin{aligned}
& C / W=4.9 \% \\
& b=0.951 \alpha^{2}-11.2 \alpha+1.91 \times 10^{2} \quad\left(R_{c}=0.947\right) \\
& C / W=13.8 \% \\
& b=2.21 \alpha^{2}-22.0 \alpha+5.78 \times 10^{2} \quad\left(R_{c}=0.995\right) \\
& C / W=38.5 \% \\
& b=5.29 \alpha^{2}-60.2 \alpha+3.64 \times 10^{3} \quad\left(R_{c}=0.970\right)
\end{aligned}
$$

Fig.6に， $P_{\alpha}=31.75 \sim 432.0 \mathrm{~N} / \mathrm{cm}$ における $\alpha$ との 関係を示している. $S_{s}$ の值はそれぞれ， $C / W=4.9 \%$ で $12.7 \sim 75.5 \mathrm{kPa}, C / W=13.8 \%$ で $111 \sim 352 \mathrm{kPa}$, 


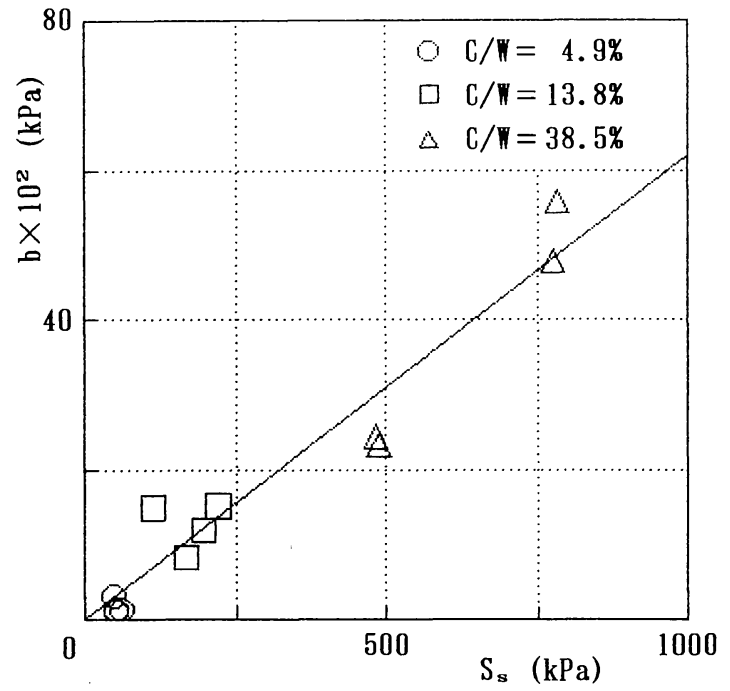

Fig.7 Relations between coefficient of penetration resistance $b$ and shear strength $S_{s}\left(\alpha=-20^{\circ} P_{\alpha}=30.87 \sim 310.0 \mathrm{~N} / \mathrm{cm}\right)$

$C / W=38.5 \%$ で $307 \sim 733 \mathrm{kPa}$ である. 図中のデータ は各 $\alpha, C / W$ での平均值であり，曲線は式 (13) (15) の回帰曲線を表す。いずれの $C / W$ の場合も, $b$ が最小 となるのは，つまり掘削刃が最もくい込みやすいのは， $\alpha \fallingdotseq 10^{\circ}$ の場合であり, 畠 ${ }^{7)}$ の切削強度指数 $0.225 \mathrm{~N} / \mathrm{cm}^{3}$ の土について行った実験結果とよく一致している.すな わち， $\alpha \fallingdotseq 10^{\circ}$ においては, 掘削刃のにげ面と刃先の進 行軌跡との交差角が最低となりくい込み抵抗のにげ面で の作用域が最も減少するために，くい込み抵抗 $b t \cdot$ $d t / d X$ は最小值をとり刃先は最もくい込み易くなるので ある.また， $\alpha \leqq 0^{\circ}$ で実験を行った $\alpha$ の数が少ないので 断定はできないが， $\alpha \leqq 0^{\circ}$ の場合は，そのまま $\alpha$ の符号 を負にした結果が予想される．つまり， $b$ 軸を対称軸と して線対称に近い曲線が $\alpha \leqq 0^{\circ}$ 側にも描かれると思われ る.

Fig.7 は, $\alpha=-20^{\circ}, P_{\alpha}=30.87 \sim 310.0$ N/cmにおけ る $S_{s}$ と $b$ の関係を表している. 図中のデー夕は実測值 である. 図より， $S_{s}$ の值が大きくなると， $b$ の值も大き くなっている.ここでは $\alpha=-20^{\circ}$ の場合を一例として 示したが，他の $\alpha$ でも同様の結果が得られた. 即ち, 軟岩強度が強くなると， $\alpha$ にかかわらず掘削刃はくい込 みにくくなることが分かる。

\section{6. 刃先の軌跡}

非定常掘削における刃先の軌跡は, 掘削深さ $t$ が変化 するため解明が困難である．逆に，刃先の軌跡を正確に 求めることができれば, 掘削土量を算定することができ, さらには作業能力をも導き出すことができる.また，刃 先の軌跡は 4 節で述べた鉛直貫入力 $P_{\alpha}$ の他に鉛直掘削

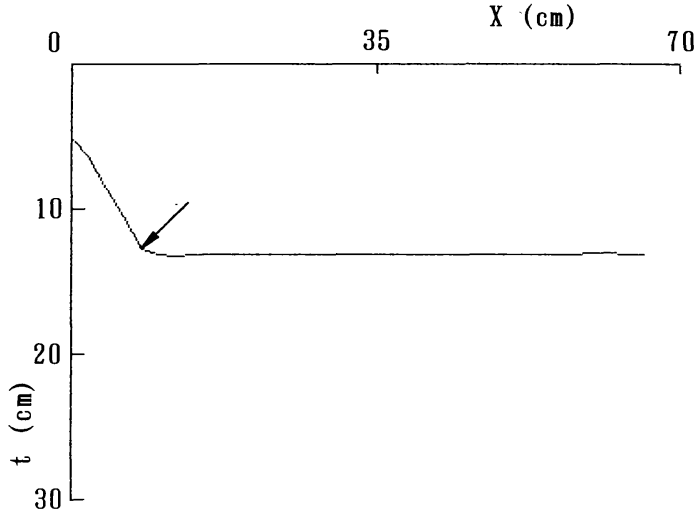

Fig.8 Relation between excavation depth $t$ and excavation length $X\left(\alpha=10^{\circ} \mathrm{C} / W=13.8 \% P_{10}=183.8 \mathrm{~N} / \mathrm{cm}\right)$

抵抗 $V_{\alpha}$ とも密接に関係しており, 軟岩のせん断強度 $S_{s}$ をパラメータとして考察する必要がある.このように, 刃先の軌跡を明確にすることは, 非定常掘削機構を解明 していく上で非常に有効である.

まず，実験結果の一例として, Fig. 8 に $\alpha=10^{\circ}, C / W$ $=13.8 \%, P_{10}=183.8 \mathrm{~N} / \mathrm{cm}$ の場合の刃先の軌跡, 即 ち $X$ と $t$ の関係を示す. 図より $t$ は, 掘削開始後に急に 深くなった後，ほぼ一定となっている．前図 Fig.2に示 す $V_{\alpha}$ と $t$ の挙動とを対応させてみるとよく分かるが， $t$ が一定となり始める $X$ は, $V_{\alpha}$ が一定值に落ち着き始め る $X$ と一致している. $t$ が一定となるということは, 刃 先の貫入がなくなりくい込み抵抗がほぼ 0 になることで あるので, 式 (12) は $P_{\alpha} \fallingdotseq V_{\alpha}$ となり, $V_{\alpha}$ が一定值 $P_{\alpha}$ に落ち着くわけである.また, 式 (12) の $d t / d X$ は軌 跡の勾配であり, 掘削刃のにげ角 $\gamma=50^{\circ}$ と一致すると きの $X$ は 7.5〜8.0 cm の間となり，その位置を同図に 矢印で示した.この位置は $V_{\alpha}$ が極小值をとった直後で ある・

次に，5節で述べた式 (12) を積分することによって, 刃先の軌跡の算定値 $t=f(X)$ を導いた. 積分する際, $V_{\alpha}$ には 4 節で算出した鉛直掘削抵抗実験式を代入して 行った. また, $b$ および初期条件としての初期貫入深さ $t_{0}$ が必要であるが，実験で得られた $b, t_{0}$ は限られた条 件下でのものである. よって, $b, t_{0}$ に一般性を持たせ るため, $P_{\alpha}, S_{s}$ を独立変数とし, 実験より得られた $b$, $t_{0}$ を従属変数として重回帰分析を行い, $b$ および $t_{0}$ を $P_{\alpha}, S_{s}$ の関数で表し，それらを代入して積分を行った。 数学的に積分を行うことは非常に困難であると思われた ので, SIMPSON の数值積分法を用いて計算機により 積分値を算出した.

上記のような積分により得られた軌跡の算定值 $t=f$ （X）と実測值を比較したものが，Fig.9 である. $\alpha=$ $10^{\circ}$ において, $P_{\alpha}, S_{s}$ が異なる場合を二例示している。 


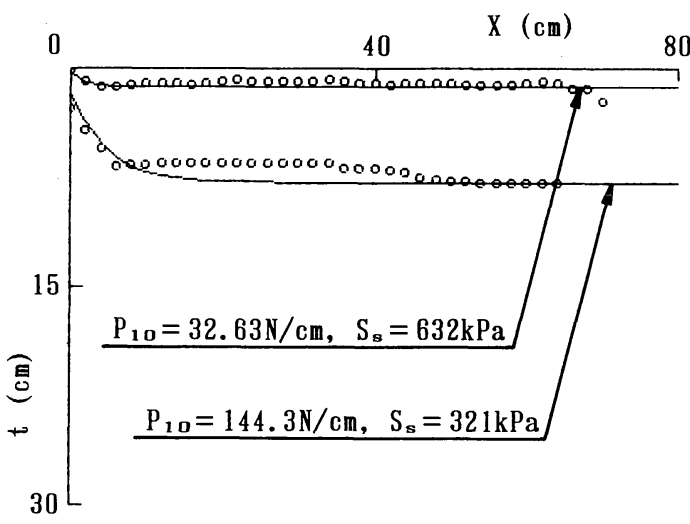

Fig.9 Relations between excavation depth $t$ and excavation length $X$ for various penetration force $P_{10}$ and shear strength $S_{s}\left(\alpha=10^{\circ}\right)$

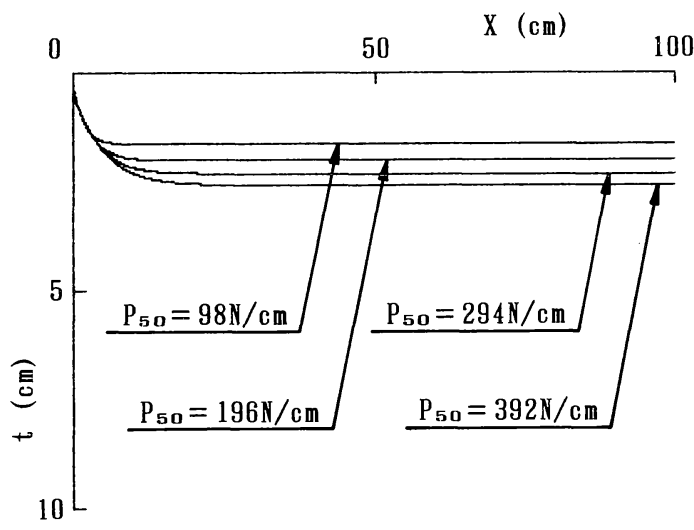

Fig.10 Relations between excavation depth $t$ and excavation length $X$ for various penetration force $P_{50}\left(\alpha=50^{\circ} S_{s}=\right.$ $588 \mathrm{kPa})$

図中のデータが奉測値であり実線が算定值であるが，い ずれの場合も両者は良く一致している.

Fig.10 は, $\alpha=50^{\circ}, S_{s}=588 \mathrm{kPa}$ において, $P_{50}$ が変 化した場合の $t$ の算定值曲線を示したものである. 当然 のことであるが， $P_{50}$ が大きくなると $t$ も深くなってい る. しかし， $\alpha$ が小のものと比べると, $P_{\alpha}$ が増加して も $t$ の值にそれほど大きな差はない ${ }^{8)}$.これは， $\alpha$ が大 きくなるとにげ角が小さくなり，供試体と接するにげ面 の面積が大きくなり深く貫入しないためである．にげ面 とは掘削刃の裏面のことであり，にげ角とは水平面とに げ面がなす角度のことである．また， $t$ が一定となる理 由としては次のように考える. まず, 掘削し始めた初期 の部分ではまだ掘削した土も少ないので, 掘削刃は深く 貫入しようとする. しかし, 掘削が進んで掘削刃前方に 土が盛り上がってくると, 掘削刃の貫入エネルギーは小 さくなり, 掘削エネルギーの大半が掘進エネルギーに変 換されてしまう. 故に, 掘削刃に与えられるエネルギー

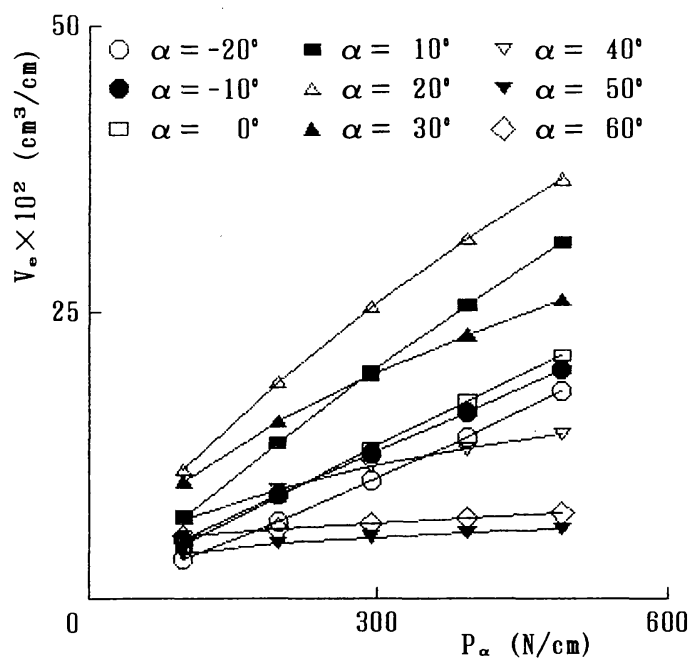

Fig.11 Relations between excavation volume $V_{e}$ and penetration force $P_{\alpha}$ for various rake angle $\alpha\left(S_{s}=196 \mathrm{kPa}\right)$

のすべてが掘進エネルギーとして費やされ, 貫入エネル ギーが 0 となったとき， $t$ が一定となるわけである。な お，掘削刃の単位刃幅当たりの貫入エネルギーについて は, 軟岩のせん断変形に要する仕事量及び掘削刃にげ面 における摩擦仕事量を考慮する必要があり, 今後の研究 課題としたい.

\section{7. 掘削土量}

定常掘削では, 掘削深さ $t$ は既知であるので掘削土量 の算定は容易である. しかし, 非定常掘削では $t$ が変化 するため, 掘削土量を正確に求めることは極めて困難で ある，それゆえ，掘削土量を的確に予想することは，非 定常掘削機構を知る上で, 重要かつ不可欠なことである. 本節では, 前節で算出した刃先の軌跡の算定値曲線を用 いて,さらに様々な条件下における掘削土量 $V_{e}\left(\mathrm{~cm}^{3} /\right.$ $\mathrm{cm})$ を算定することができるプログラムを作成し, 解 析・考察した.この節で掘削土量 $V_{e}$ とは, 掘削距離 $X$ $=100 \mathrm{~cm}$, 奥行き $1 \mathrm{~cm}$ の場合の, $X$ 軸と算定値曲線 $t$ $=f(X)$ で囲まれた部分の面積とした.つまり，掘削 刃が $100 \mathrm{~cm}$ 掘削を行った際の単位幅当たりの掘削土量 を取り扱っている.

Fig.11に, $S_{s}=196 \mathrm{kPa}$ の場合の $P_{\alpha}$ と $V_{e}$ の関係を 示す. 図中のデータは上記のようにして算出したもので ある. 図よりまず，いかなる $P_{\alpha}$ においても $\alpha=20^{\circ}$ が $V_{e}$ 最大となっている. そして, $P_{\alpha}$ が増加していくと, $\alpha=10^{\circ}$ も $\alpha=20^{\circ}$ に次いで有効な $V_{e}$ が得られるようで ある.また， $\alpha$ が大きくなると， $P_{\alpha}$ の増加に対する $V_{e}$ の増加の勾配が他と比べて緩やかなものとなっている. 特に, $\alpha=50^{\circ}, 60^{\circ}$ では， $V_{e}$ において $P_{\alpha}$ を変化させる 効果は非常に小さいといえる，これは，にげ面及びにげ 


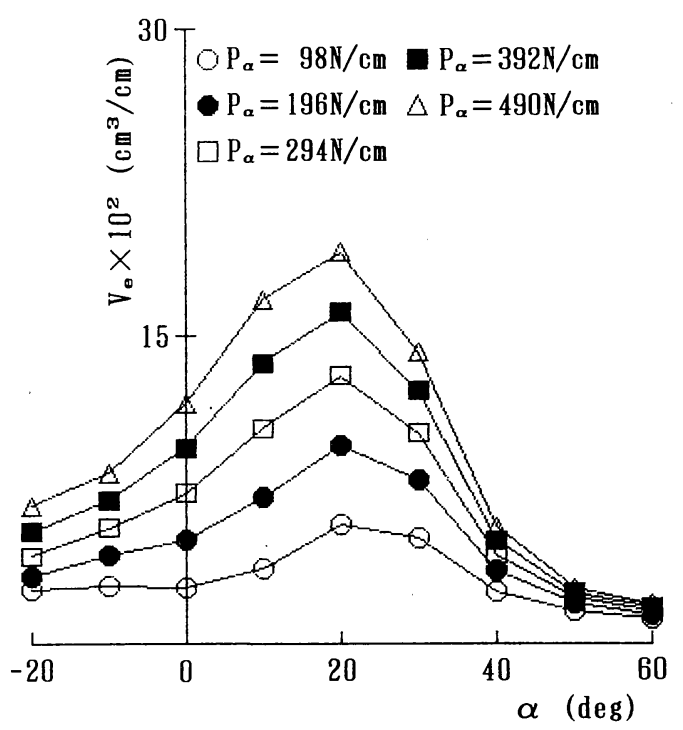

Fig.12 Relations between excavation volume $V_{e}$ and rake angle $\alpha$ for various penetration force $P_{\alpha}\left(S_{s}=588 \mathrm{kPa}\right)$

角が掘削において影響を及ぼしているものと考えられ る.

Fig.12 は， $S_{s}=588 \mathrm{kPa}$ における $\alpha$ と $V_{e}$ の関係であ る. 前図同様図中のデータは算定值である. すべての $\alpha$ で $P_{\alpha}$ が大きくなると $V_{e}$ も増加しているが，前図の説 明で述べたように， $\alpha \geqq 40^{\circ}$ では $P_{\alpha}$ による $V_{e}$ の変化は 小さい. $\alpha<0^{\circ}$ でも, $0^{\circ} \leqq \alpha \leqq 30^{\circ}$ と比べると同様のこと がいえるが，これはすくい面の影響であると推測される. ここでは例として $S_{s}=588 \mathrm{kPa}$ の場合を示したが，他 の $S_{s}$ での解析からもこの図とほほ同様の結果が得られ た.つまり， $P_{\alpha}, S_{s}$ に関わらず，常に効果的な $V_{e}$ が期 待できるのは, $\alpha=10^{\circ}, 20^{\circ}$ である.

次に, $S_{s}$ と $V_{e}$ の関係について調べたが, この二つの 関係は, $S_{s}$ の減少に対して $V_{e}$ が増加する直角双曲線に 近い関数形で表される傾向がある. よって, $V_{e}$ を従属 変数亡し, $S_{s}, P_{\alpha}$ を独立変数として重回帰分析を行い, $V_{e}\left(\mathrm{~cm}^{3} / \mathrm{cm}\right)$ を $S_{s}(\mathrm{kPa}), P_{\alpha}(\mathrm{N} / \mathrm{cm})$ の関数として 各 $\alpha(\mathrm{deg})$ ごとに表すと, 以下の式が成立した.

$$
\begin{aligned}
& V_{e-20}=8.39 \times 10^{2} S_{s}^{-0.766} P_{\alpha}^{0.771} \\
& V_{e-10}=1.06 \times 10^{3} S_{s}^{-0.758} P_{\alpha}^{0.753} \\
& V_{e 0}=1.36 \times 10^{2} S_{s}{ }^{-0.558} P_{\alpha}^{0.926} \\
& V_{e 10}=2.74 \times 10^{2} S_{s}^{-0.612} P_{\alpha}^{0.923} \text {. } \\
& V_{e 20}=9.50 \times 10^{2} S_{s}^{-0.592} P_{\alpha}^{0.720} \text {. } \\
& V_{e 30}=1.11 \times 10^{3} S_{s}{ }^{-0.530} P_{\alpha}^{0.578} \\
& V_{e 40}=4.62 \times 10^{3} S_{s}{ }^{-0.776} P_{\alpha}{ }^{0.452} \\
& V_{e 50}=2.43 \times 10^{3} S_{s}^{-0.602} P_{\alpha}^{0.253} \\
& V_{e 60}=4.05 \times 10^{4} S_{s}^{-1.053} P_{\alpha}^{0.206}
\end{aligned}
$$

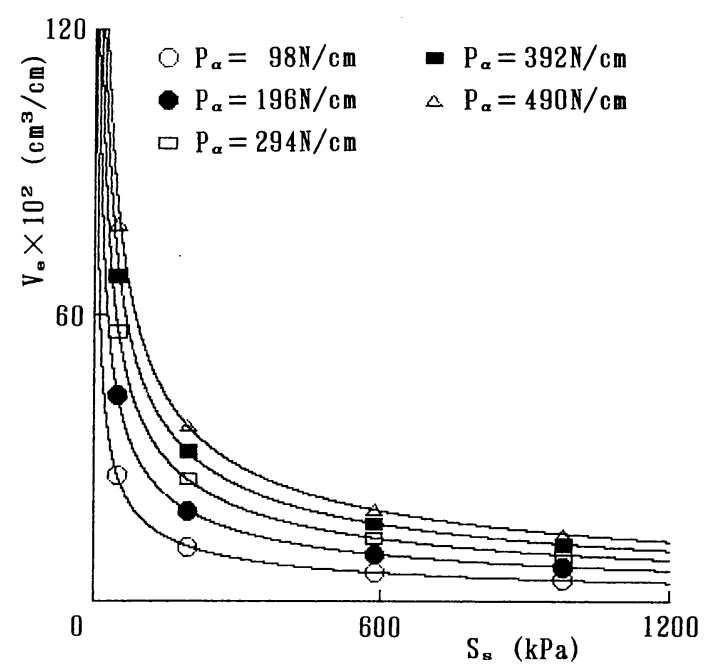

Fig.13 Relations between excavation volume $V_{e}$ and shear strength $S_{s}$ for various penetration force $P_{\alpha}\left(\alpha=20^{\circ}\right)$

$V_{e}$ の添字はすくい角を表す. Fig.13に， $\alpha=20^{\circ}$ の場合 を一例として $S_{s}$ と $V_{e}$ の関係を示している. 図中のデ夕はこれまで同様算定值であり, 曲線は式 (20) の回帰 曲線を表すが，両者は良く一致している. すべての $P_{\alpha}$ で $S_{s}$ の值が小さい方が $V_{e}$ が増大するのは明白である. そして,$P_{\alpha}$ が大になるほど, $S_{s}$ の減少に対する $V_{e}$ の 増加の割合は大きくなっている. また, 式 (23), (24) を見ると， $P_{\alpha}$ の指数が式 $(16)$ 一式(22) と比べてかな り小さくなっている. 即ち, $\alpha$ が $50^{\circ}, 60^{\circ}$ と大きくな ると, $P_{\alpha}$ を大きくして $V_{e}$ を増大させようとすること は，あまり効果は期待できないといえる.

以上, 掘削土量についてのいくつかの解析・考察を 行ったが, 掘削土量を多く得るということは掘削刃が深 くまで貫入することを意味し，5節で述べた貫入抵抗係 数の值が小さいときに, その条件の一つを満たすもので ある ${ }^{9)}$. 5 節によれば，貫入抵抗係数が最小となるのは すくい角が約 $10^{\circ}$ のきであり,この節での解析結果と ほぼ一致している.

\section{8. 実機への適用}

この節では, 本研究の実験・解析の妥当性, 実用性を 確認するため， 7 節までに得られた情報をすべて駆使し て掘削土量についてシミュレーション解析を行い, 実機 への適用を試みた. 基本的な解析手法は 7 節の掘削土量 についてと同様であるが，実機では掘削距離によってす くい角が変化することに留意して解析した. このシミュ レーション解析では, 阪神高速湾岸線魚崎浜高架橋基礎 に採用された連壁基礎の施工 ${ }^{10}$ で稼働した, 䀣垂式油圧 クラムシェル掘削機を用いた. 以下にその実機の仕様を 示す. 


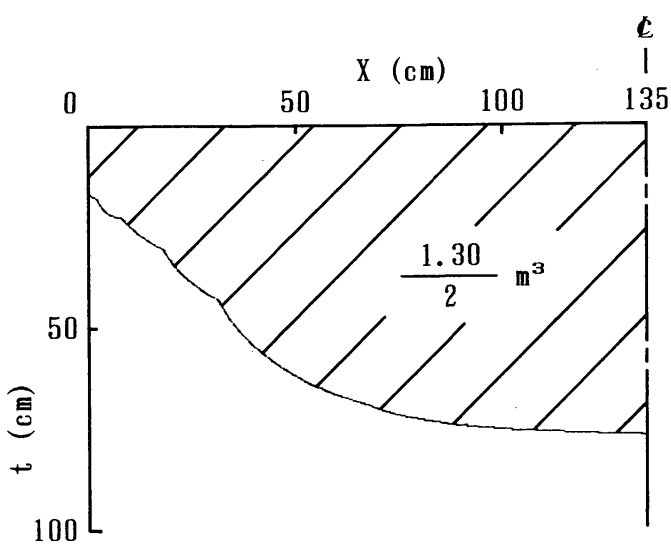

Fig.14 Relations between excavation depth $t$ and excavation length $X\left(P_{\alpha}=612.5 \mathrm{~N} / \mathrm{cm} S_{s}=196 \mathrm{kPa}\right)$

\begin{tabular}{ll}
\hline バケット幅 & $: 800 \mathrm{~mm}$ \\
容量 & $: 0.98 \mathrm{~m}^{3}$ (平積み) \\
自重 & $: 98 \mathrm{kN}$ \\
最大掘削可能距離 & $: 1350 \mathrm{~mm}$ \\
刃先角 & $: 20(\mathrm{deg})$
\end{tabular}

対象地盤は $N$ 値 30 程度の洪積砂硆層之洪積粘土層の互 層地盤で地山密度 $1.90 \mathrm{Mg} / \mathrm{m}^{3}$, 非排水せん断強度 196 $\mathrm{kPa}$ である. 上記のような実機の諸元及び対象地盤の せん断強度を入力情報とし, バケット刃先の軌跡之掘削 土量を出力情報としてシミュレーション解析を行った.

Fig.14に, 対象地盤のせん断強度 $S_{s}=196 \mathrm{kPa}$ とし た場合のシミュレーション解析結果を示す．鉛直貫入力 $P_{\alpha}$ は, 実機の自重を単位刃幅当たりに換算し, $P_{\alpha}=$ $612.5 \mathrm{~N} / \mathrm{cm}$ としている. すくい角がー $20^{\circ}$ の掘削範囲 から $10^{\circ}$ ごとにバケットが閉合するときのすくい角 $60^{\circ}$ までの各掘削範囲において, それぞれの掘削刃の軌跡か ら掘削土量を算定した．累算した結果, 片方のバケット 翼による総掘削土量は $0.65 \mathrm{~m}^{3}$ であり, 当該バケットに よる総掘削土量は $1.30 \mathrm{~m}^{3}$ と算定された。この場合, 算 定掘削土量は実機のバケット容量を多少オーバーしてい る. 実機のバケット容量は平積みでの掘削後の土量を表 したものであるが，ここでの算定掘削土量は地山密度に おける最大掘削土量を表す。よって, 実機でも算定され た土量は掘削可能であるが，実際はほぼ定格容量に近い 掘削実績を得ている。これは, 連壁掘進中のバケットの 姿勢制御を行うために，バケットの全自重を地盤に伝達 していないことによると考える。 また，バケット刃先部 または積込上面部からの土砂の漏洩も無視することはで きない.

また，ここで採用した実機以外にも，種々の自重即ち $P_{\alpha}$ および $S_{s}$ において, 合計 25 種類のシミュレーショ ン解析を行った. その結果, 得られた掘削土量 $V_{e}^{\prime}\left(\mathrm{m}^{3}\right)$ 之 $S_{s}$ の関係は, 前節と同様, 直角双曲線に近い関数形

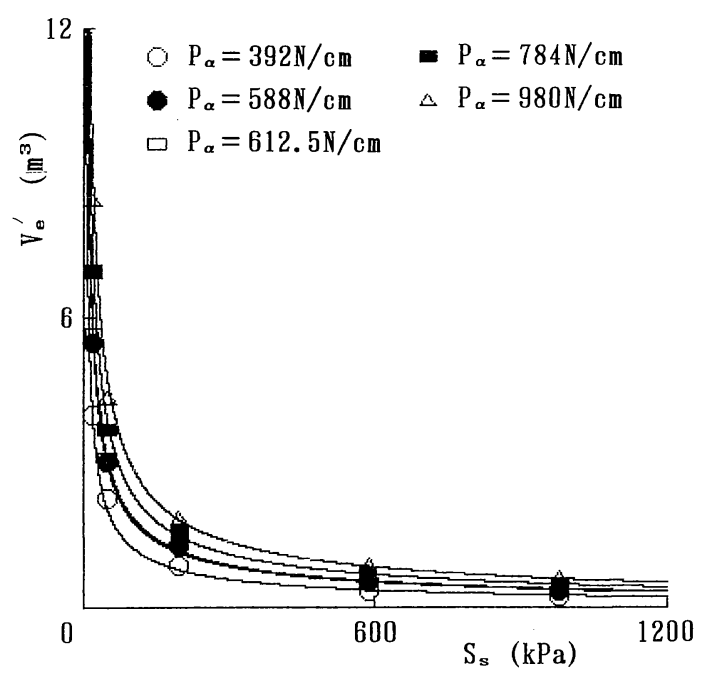

Fig.15 Relations between excavation volume $V_{e}^{\prime}$ and shear strength $S_{s}$ for various penetration force $P_{\alpha}$

で表され， $S_{s}$ の減少に対して $V_{e}^{\prime}$ が増加している.よっ て, $V_{e}^{\prime}$ を $S_{s}, P_{\alpha}$ の関数として表し重回帰分析を行っ た結果, 次式を得た。

$$
V_{e}^{\prime}=0.120 S_{s}^{-0.696} P_{\alpha}^{0.928} \text {....... }
$$

Fig.15 は, シミュレーション解析から得られた $V_{e}^{\prime}$ と $S_{s}$ の関係を表したものである. 図中の曲線が式 (25) の回帰式を表すが, デー夕と回帰曲線は良く一致してい る. 図より， $S_{s}$ の値が大となると $V_{e}^{\prime}$ は著しく減少する が, 同じ $S_{s}$ の軟岩盤に対して $V_{e}^{\prime}$ は $P_{\alpha}$ 即ち実機の自重 にほぼ比例して増大することが明らかとなった。

\section{9. 結 論}

非定常掘削機構を詳細に解明し, より正確に把握して いくことは, 数多くあるこの機構を有した掘削機械に対 して有益な設計指針を与えるものであり, 重要かつ不可 欠な課題である。ここでは, 海底岩盤となりうる軟岩を 対象とした種々の非定常掘削実験結果に基づき, その刃 先作用力と掘削土量に主眼をおいて解析を行った.また, 得られた実験結果および解析結果をすべて網羅したシ ミュレーション解析を行い, 実機への適用を試み, 同時 に実験・解析の実用性, 妥当性を検討した. 以下に得ら れた知見を示す.

（1）すくい角が $\alpha$ のときの水平掘削抵抗 $H_{\alpha}$ $(\mathrm{N} / \mathrm{cm})$ および合掘削抵抗 $R_{\alpha}(\mathrm{N} / \mathrm{cm})$ は, 掘削距離 $X(\mathrm{~cm})$, 鉛直貫入力 $P_{\alpha}(\mathrm{N} / \mathrm{cm})$, 軟岩のせん断強度 $S_{s}(\mathrm{kPa})$ およびすくい角 $\alpha(\mathrm{deg})$ の関数として, 式 ( 8$)$ 一式 (11) で表すことができる.また，鉛直掘削抵抗 $V_{\alpha}(\mathrm{N} / \mathrm{cm})$ は， $H_{\alpha}, R_{\alpha}$ を用いて次式で表される. 


$$
V_{\alpha}= \pm \sqrt{{R_{\alpha}}^{2}-H_{\alpha}{ }^{2}} \quad\left(\beta>0: V_{\alpha}>0, \beta<0: V_{\alpha}<0\right)
$$

（2）貫入抵抗係数 $b(\mathrm{kPa})$ は, すくい角 $\alpha\left(\geqq 0^{\circ}\right)$ の 2 次関数として, 各セメント水比 $C / W(\%)$ ごとに 式 (13) 〜式 (15) で表される. そして, 同係数は $\alpha \fallingdotseq$ $10^{\circ}$ のときに最小值をとり, 軟岩のせん断強度 $S_{s}(\mathrm{kPa})$ が大きくなると, 大となる.つまり, 掘削刃が最も貫入 しやすいのはすくい角が $10^{\circ}$ の場合であり, 軟岩強度が 強くなると，すくい角に関わらず掘削刃はくい込みにく くなる.

（3）刃先の軌跡は, 式 (12)を積分することによっ て算定することができる. そしてその軌跡より，すくい 角が大きくなると, 掘削深さ $t(\mathrm{~cm})$ に及ぼす鉛直貫入 力 $P_{\alpha}(\mathrm{N} / \mathrm{cm})$ の影響は, すくい角が小さいものと比べ てかなり小さいといえる.

(4) 刃先の軌跡より算出された掘削土量 $V_{e}$ $\left(\mathrm{cm}^{3} / \mathrm{cm}\right)$ は, すくい角が $10^{\circ} \sim 20^{\circ}$ のときに, 鉛直貫 入力 $P_{\alpha}(\mathrm{N} / \mathrm{cm})$, 軟岩のせん断強度 $S_{s}(\mathrm{kPa})$ にかか わらず常に効果的なものが期待できる. また $V_{e}$ は， $S_{s}$ の減少に対して増加する式 (16) 〜式(24) の直角双曲線 に近い関数形で表すことができる. そして, それらの式 より，すくい角が $50^{\circ}, 60^{\circ}$ と大きくなると， $P_{\alpha}$ を大き くして $V_{e}$ を増大させようとすることは, あまり効果は 期待できないことが判った。

（5）シミュレーション解析により算出される掘削土 量は, 実機のバケット容量を多少オーバーしたものを与 える.しかしこれは，バケット自重の地盤への伝達率や バケットから漏洩する土砂, 現場条件等を考慮に入れる 必要がある. また, その掘削土量 $V_{e}^{\prime}\left(\mathrm{m}^{3}\right)$ 亡軟岩のせ ん断強度 $S_{s}(\mathrm{kPa})$ 及び鉛直貫入力 $P_{\alpha}(\mathrm{N} / \mathrm{cm})$ の関係 は, 次式で示す直角双曲線に近い関数形で表されること が判明した。

$$
V_{e}^{\prime}=0.120 S_{s}^{-0.696} P_{\alpha}^{0.928}
$$

$S_{s}$ が大きくなると, 掘削土量 $V_{e}$ は著しく減少するが,
一定の軟岩強度 $S_{s}$ を有する岩盤掘削においてはバケッ 卜の自重に相当する鉛直貫入力 $P_{\alpha}$ にほぼ比例すること が判明した.さらに, 掘削土量を増大させるには, バケッ ト自重を増大させるばかりでなく，バケットのすくい角 や刃先角を変化させてみることも一つの手段であると示 唆される. なお, 本研究は平成 3 年度文部省科学研究費 (一般研究 C) 課題番号 03650410 の補助を受けて遂行 されたものであることを付記しておく.

\section{参 考 文 献}

1) ISRM Commission on Standardization of Laboratory and Field Test: Suggested Methods for the quantitative description of discontinuities in rock masses, Int. J. Rock Mech. Min. Sci. \& Geomech. Abster. Vol.15, pp.225 319, 1967.

2）小林良二・奥村清彦：岩石のせん断について, 日本鉱業 会誌, Vol.87, No.999, pp. 407〜412, 1971.

3）室達朗・深川良一・藤田克美：軟岩に対する比切削抵抗 之定常掘削力の発生機構, 土木学会論文集, 第 424 号, III-14, pp. 125 133，1990.

4）笈田昭：土のせん断応力一変位曲線表示式に関する一考 察, 農業機械学会誌, 第 37 巻第 1 号, pp. 20 25, 1975.

5）畠昭治郎：土の掘削について, 建設機械, Vol.19, No.4, pp. 30 35, 1983.

6）畠昭治郎：土の掘削機構について, 土と基礎・最近の工 法, 土質工学会, pp. 1〜6, 1967.

7）畠昭治郎：掘削機構の解明（1）(その 1 ), 建設の機械化, 第 135 号, pp. 71 74, 1961.

8）室達朗・渡辺裕明：軟岩の非定常掘削における刃先の軌 跡, 愛媛大学工学部紀要, 第 12 巻第 3 号, pp. 145 154, 1992.

9）室達朗・渡辺裕明：軟岩に対する非定常掘削機構の解明, テラメカニックス, 第 11 号, pp. 33〜39, 1991.

10）長野敏郎 - 西田隆治 - 鈴木睦 - 細井武 - 岩永克也 - 平野 孝行: 小断面連壁基礎の安定解析之施工 (阪神高速湾岸 線魚崎浜高架橋基礎の施工), 西松建設技報, Vol.12, pp. 72 90, 1989.

(1992.3.13 受付)

\section{EXPERIMENTAL STUDY ON EXCAVATION FORCES OF BUCKET SHOVEL AGAINST SOFT ROCK MASS}

Tatsuro MURO, Ryoichi FUKAGAWA and Hiroaki WATANABE

To analyse the mechanism of unsteady excavation of soft rock mass, several experimental tests were carried out for various rake angles and normal penetration forces acting on the cutting edge. As the results, the cutting resistance in unsteady excavation could be expressed as a function of excavation length, normal penetration force, shear strength of rock material and rake angle. The coefficient of penetration resistance could be expressed as a quadratic function of rake angle, which increases with the increment of shear strength of rock material, and takes a minimum value at about $10 \mathrm{de}-$ grees of rake angle. And the excavation volume of soft rock mass could be expressed as some hyperbolic function of shear strength of rock material. 